\title{
MANDATORY OCCUPATIONAL SAFETY AND HEALTH STANDARDS- SOME LEGAL PROBLEMS
}

\author{
RICHARD S. MOREY*
}

\section{INTRODUCTION}

The Occupational Safety and Health Act of $1970^{1}$ authorized for the first time the setting by the federal government of "mandatory occupational safety and health standards applicable to businesses affecting interstate commerce." 2 This authority for the detailed federal regulation of conditions relevant to industrial safety and health has already had very significant effects on American industry. It is clearly destined to have even greater influence in the future as the broad regulatory potential of mandatory safety and health standards is fully explored. This article considers a number of legal problems connected with developing mandatory standards to protect occupational safety and health, and with regulating the hazards in the industrial workplace by means of such standards.

Compliance with occupational safety and health standards is a primary duty under the Act for both the employer ${ }^{3}$ and the employee. ${ }^{4}$ The duty is nothing more than an admonition in the case of employees as there are no statutory penalties applicable to them. ${ }^{5}$ For the employer, however, the duty is much more than theoretical as the mounting number of citations ${ }^{6}$ under the Act will attest, including penalties for the employer's failure to provide stringent enough sanctions to make his employees obey. ${ }^{7}$ And the penalties can be severe, especially for repeated or willful violations or for failure to abate a violation. ${ }^{8}$

\footnotetext{
*Kleinfeld, Kaplan \& Becker, Washington, D.C.

129 U.S.C. $\$ \$ 651-78$ (1970).

2 Occ. Safety \& Health Act § 2(3), 29 U.S.C. § 651(3) (1970). Prior federal legislation on occupational safety and health was limited in scope, applying only to businesses supplying goods and services to the government and to certain industries or activities. Generally, however, such legislation did provide for establishment of mandatory standards. Such standards are the "established federal standards" referred to in the Act.

${ }^{3} I d . \S 5(\mathrm{a})(2), 29$ U.S.C. $\$ 654(\mathrm{a})(2)$.

${ }^{4} I d . \S 5(\mathrm{~b}), 29$ U.S.C. $\S 654(\mathrm{~b})$.

${ }^{5}$ See $i d$. $\$ 17,29$ U.S.C. $\$ 666$, which contains no penalties for "employees" similar to those in subsections (a) through (e) referring to employers.

${ }^{B}$ In 1972, the first full year of operation under the Act, the Occupational Safety and Health Administration (OSHA) issued approximately 24,000 citations. In 1973, the total rose to approximately 43,000. Interview with Bob Hammond, Mathematical Statistician, Office of Planning, Evaluation, and Research, OSHA, May 6, 1974.

'See Lebanon Lumber Co., 2 O.S.H.R.C. 924 (1972), modified, O.S.H.R.C. Docket No. 184 (March 17, 1973); $c f$. Intermountain Block \& Pipe Corp., 1 O.S.H.R.C. 455 (1972).

${ }^{8}$ Ordinary violations of the Act, either "serious" or nonserious, are subject to a $\$ 1,000$ fine per violation. Repeated or willful violations subject the employer to a $\$ 10,000$ fine. Failure to correct (abate) a violation within the time allotted by the Secretary of Labor, but not starting until a final order determining the violation is issued, can cost up to $\$ 1,000$ per day for the period the violation
} remains uncorrected. Occ. Safety \& Health Act \& 17, 29 U.S.C. § 666 (1970). 
The Act establishes in some detail procedures for development of standards ${ }^{9}$ and provides for their enforcement both federally ${ }^{10}$ and by the states. ${ }^{11}$ The statutory scheme of the Act emphasizes development of standards as the primary means of regulating occupational safety and health. ${ }^{12}$ It does this through a very broad definition of what may be the subject of a standard..$^{13}$ It also facilitates achievement of this objective by providing both a means of rapidly adopting a body of applicable existing standards as a preliminary basis for regulation ${ }^{14}$ and an administrative procedure for developing completely new standards. ${ }^{15}$ There is also provision for development of standards by the states both in areas not regulated by federal standards and in areas already so regulated, under specified conditions. ${ }^{16}$

The development of standards raises a number of questions ranging from how best to define the areas to be covered by standards to what techniques or requirements will be most effective in dealing with the hazards involved, both practically in the workplace and as a matter of enforcement. The place of privately developed standards and prior federal standards in the armamentarium of statutory standards also raises a number of difficulties based on the different ground rules which apply when a standard is recognized under the Act. ${ }^{17}$ Also, the procedure for development of new standards is complicated and untried. It is unclear how well it will meet the difficulties of formulating intricate, technical standards which must be both practical of application and legally enforceable while considering the often diverse views of interested persons. ${ }^{18}$ Finally, a statutory concession to federalism, giving the states a role in standard development, also presents intriguing problems. ${ }^{19}$

Interrelated with the problems of developing effective standards but deserving of separate consideration are the problems of interpretation and enforcement of statutory standards. These include questions as to the different means of avoiding a standard (such as interpretation, variance, or standard amendment), ${ }^{20}$ the various defenses to alleged standard violations, ${ }^{21}$ the relationships among possibly conflicting statutory standards and the general duty clause of the $\mathrm{Act}^{22}$ the interpretation and enforcement of federal standards by the states, ${ }^{23}$ and the relationship between statutory standards and conflicting legal requirements of other federal laws. ${ }^{24}$

${ }^{9} I d . \S 6,29$ U.S.C. $\S 655$.

${ }^{10} I d . \S \S 8-10,29$ U.S.C. $\S \S 657-59$.

${ }^{11} I d . \$ \S 18(\mathrm{~b})-(\mathrm{c}), 29$ U.S.C. $\$ \S 667$ (b)-(c).

12 See, e.g., S. REP. No. 91-1282, 91st Cong., 2d Sess. 1 (1970).

${ }^{13} \mathrm{See}$ Occ. Safety \& Health Act § 3(8), 29 U.S.C. § 652(8) (1970).

${ }^{11}$ See id. $\$ 6(\mathrm{a}), 29$ U.S.C. $\$ 655(\mathrm{a})$.

${ }^{15}$ See id. § 6(b), 29 U.S.C. § 655(b).

${ }^{18} S e e$ id. $\S$ 18(a), 18(c)(2), 29 U.S.C. $\S \S 667$ (a), 667(c)(2).

${ }^{17}$ See Part I, B infra.

${ }^{18}$ See Part I, C infra.

${ }^{19}$ See Part I, D infra.

${ }^{20}$ See Part II, A infra.

${ }^{21}$ See Part II, B, 2-3 infra.

${ }^{22}$ See Part II, B, 4 infra.

${ }^{23}$ See Part II, C infra.

${ }^{24}$ See Part II, D infra. 


\section{Development of Standards}

This section first considers the range of standard making activity contemplated under the Act. It then describes the various types of standard development which may lead to mandatory standards-private, federal, and state-and some of the legal problems which are being encountered with standards of each type.

\section{A. The Statutory Mandate}

Section 3(8) of the Act defines an "occupational safety and health standard" as "a standard which requires conditions, or the adoption or use of one or more practices, means, methods, operations, or processes, reasonably necessary or appropriate to provide safe or healthful employment and places of employment."25 Most interesting about this definition is its incredible scope and flexibility. Almost any conceivable requirement, including many which are far from the conventional concept of a standard, would appear to be permitted by this language; it is difficult to imagine any possible requirement not encompassed by the terms "conditions ... practices, means, methods, operations, or processes." The apparent circularity of the definition, that a statutory standard "means a standard which. ...," however, might be interpreted to mean that there is a recognized concept referred to as a "standard" which any requirement must meet to fulfill the statutory definition. Thus, a certain requirement might be invalid because it does not accord with the recognized concept of a standard in terms of subject matter, feasibility, concreteness, and so forth. The only other apparent restriction in the definition is that the requirement have some bearing, that is, be "reasonably necessary or appropriate" to occupational safety or health.

The broad scope of the statutory definition is confirmed in section 6 of the Act which specifies that standards may include requirements for the use of labels and other warnings, prescription of suitable protective equipment, and provision for various tests including medical examinations of employees. ${ }^{26}$ Section 6 provides further latitude in its description of the development of standards and the statutory criteria against which they are to be measured: standards may, but need not be, the product of recommendations by a nationally recognized standards-producing organization, the National Institute of Occupational Safety and Health (NIOSH), or a statutory advisory committee. ${ }^{27}$ Standards are to be based on "research, demonstrations, experiments, and such other information as may be appropriate."28 In short, anything the Secretary of Labor finds persuasive can be the basis for a standard.

The statutory criteria for standards might provide some limit to standard

${ }^{25}$ Occ. Safety \& Health Act $\S 3(8)$, 29 U.S.C. $\$ 652(8)$ (1970).

${ }^{26} I d . \S 6(\mathrm{~b})(7), 29$ U.S.C. $\S 655(\mathrm{~b})(7)$.

${ }^{27}$ Id. § 6(b)(1), 29 U.S.C. \$ 655(b)(1). In Industrial Union Dep't, AFL-GIO v. Hodgson, 499 F.2d 467 (D.C. Cir. 1974), the court rejected the petitioners' argument that determinations of NIOSH on medical or scientific questions must be followed by OSHA.

${ }^{28}$ Occ. Safety \& Health Act § 6(b)(5), 29 U.S.C. § 655(b)(5) (1970). 
making activity, but they do not appear to do so in practical terms. The first specified criterion for a standard is "the highest degree of health and safety protection for the employee."29 But "the latest available scientific data" as well as "feasibility" ${ }^{30}$ and "experience" are equally to be considered. ${ }^{31}$ There is also the requirement that if "practicable" a standard must be stated in terms of "objective criteria." 32 The fundamental problem with these statutory criteria is that they are broad, ambiguous, and even contradictory. It is unlikely that attaining the absolute "highest degree" of protection will be either "feasible" or in accord with "experience" in many cases. There often will be a similar conflict with the requirement of "objective criteria." Thus, in effect, the decision is left to the Secretary to choose among these conflicting values, and his decision is subject only to limited review by the courts. ${ }^{33}$

One example of the latitude available under the Act is the choice between so-called "vertical" standards applying only to a specific industry or manufacturing process and "horizontal" standards applicable generally to all industrial workplaces. Section $6(\mathrm{~g})$ of the Act seems to suggest vertical standards in requiring the Secretary to consider the needs of particular industries and work environments in establishing standards. ${ }^{34}$ Nonetheless, the majority of presently effective standards are horizontal standards, ${ }^{35}$ and it appears to be the agency's policy to continue with the promulgation of such standards. Generally applicable "horizontal" standards have the virtue of covering the most workplaces most quickly. But they also present problems both in imposing unnecessarily strict requirements on some workplaces and in probably not providing as much protection as needed in other situations. ${ }^{36}$

The statute thus grants to the Secretary of Labor extremely wide ranging authority to promulgate standards-as to the type of requirements to be imposed, the level of protection to be provided, and which industrial workplaces are to be subjected to such requirements. Certain specific working conditions are placed outside the jurisdiction of the Act in deference to the other federal agencies regulating them. ${ }^{37}$ The only general limitation on standard making activity of practical significance, however, is procedural, in terms of compliance with the statutory standard adoption process.

\section{B. Adoption of Prior Private Standards}

Privately developed standards form the basis for most of the presently

${ }^{29} I d$.

${ }^{30}$ The concept of feasibility includes an appropriate consideration of economic as well as technological factors. See Industrial Union Dep't, AFL-CIO v. Hodgson, 499 F.2d at 477-78.

${ }^{31}$ Occ. Safety \& Health Act $\$ 6(b)(5), 29$ U.S.C. $\$ 655(b)(5)(1970)$.

${ }^{32} I d$.

${ }^{33} I d$. $\S 6(f), 29$ U.S.C. $\S 655(f)$. Section $6(f)$ provides for judicial review of standard promulgation under a "substantial evidence" standard of review. See Part I, C infra.

${ }^{34}$ Occ. Safety \& Health Act $\S 6(\mathrm{~g}), 29$ U.S.C. $\$ 655(\mathrm{~g})(1970)$.

35 There is one small group of "special industry" standards. See 29 C.F.R. $\$ \$ 1910.261-.269$ (1973). Most of the present standards apply to particular hazards, conditions, and means of controlling hazards without limitation as to industry. See generally id. $\$ 1910$.

${ }^{36}$ In Industrial Union Dep't, AFL-CIO v. Hodgson, 499 F.2d at $478-81$, the court remanded to OSHA for further consideration whether the uniform effective date of the asbestos standard could be changed to specify individual effective dates on an industry-by-industry basis.

${ }^{37}$ See Part II, D, 1 infra. 
effective standards under the Act, ${ }^{38}$ and the problems associated with private standard development are the genesis of present difficulties with a number of the statutory standards. Private standard development covers a broad, longstanding, and amorphous set of activities performed by different groups with widely varying characteristics as to membership, representation of interested parties, technical competence, and objectives. The standards so produced often have a bearing on occupational safety or health, whether or not this was their primary objective or even an important consideration in their development. In many instances a standard will have been designed mainly to protect the public rather than affected employees, or for some other purpose such as standardization of materials or procedures. Whether these other objectives are entirely compatible with occupational safety and health is often open to question. ${ }^{39}$

In addition, private standards were often written as goals to be attained rather than as rules intended to be enforced. ${ }^{40}$ Many contain specific disclaimers that they are not intended to be used as "legal standards." 11 Many combine arbitrary levels, values, or other requirements with an either explicit or implicit understanding that these requirements are not to be applied by rote to every situation which they might literally cover. They are instead to be used as guidelines in the exercise of informed judgment by sophisticated safety professionals who are aware of the basis and limitations of the information upon which the standard is based and the situations to which it reasonably may be applied. ${ }^{42}$ A largely unanswered legal problem is what happens when the Occupational Safety and Health Administration (OSHA) adopts such a standard as a consensus standard under section 6(a) of the Act ${ }^{43}$ and insists upon applying rigorously the absolute requirements set forth in the standard, deleting or ignoring the exceptions to, and understandings about, the prior nonstatutory standard.

Since section 6(a) of the Act is solely a mechanism for adopting existing national consensus and established federal standards, it would appear that any OSHA standard promulgated under its authority must be, in operational effect, the same as the standard upon which it is based. This was recognized by the Associate Solicitor for Occupational Safety and Health when he advised the agency that: "[The Secretary] is without authority under Section 6(a) to so modify the operative provisions of a consensus standard that an employer could be in compliance with the consensus standard and in violation of the

\footnotetext{
${ }^{38}$ Most present OSHA standards are based on "consensus standards" developed under the auspices of the American National Standards Institute (ANSI) or the National Fire Protection Asso. ciation (NFPA).

${ }^{39}$ Similar but converse questions arise under the Act; the safety of the general public (rather than just employees) and the effect on the environment do not appear to be recognized as valid considerations in developing and enforcing standards under the Act. See Part II, D, 2 infra. ${ }^{40}$ See Address by Robert D. Moran, Chairman, Occupational Safety and Health Review Commission before the California Newspaper Publishers Association, Feb. 15, 1974.

${ }^{41}$ See, e.g., United States of America Standard (USAS), Acceptable Concentrations of Lead and its Inorganic Compounds, USAS Z37.11-1969.

${ }^{42}$ Id. See also American National Standards Institute, American National Standard 01.1-1971, $\S 6$ (woodworking machinery), considered in Weyerhauser Co., 3 O.S.H.R.C. 994 (1973).

${ }^{13}$ Occ. Safety \& Health Act \& 6(a), 29 U.S.C. § 655(a) (1970).
} 
OSHA Standard." 44 Similarly, Judge Rubin held in the Oberhelman-Ritter Foundry case ${ }^{45}$ that the Secretary could not make mandatory in the OSHA standard a provision which was voluntary under the prior consensus standard. This principle has been reinforced by ail the decisions of the Commission and its judges which have looked to a prior consensus or federal standard to interpret an OSHA standard. ${ }^{46}$

Certainly, as held in Oberhelman-Ritter, the specific language of the prior standard cannot be ignored. But beyond that, it would seem that OSHA standards must be interpreted and applied in a manner consistent with that in which the prior standard was interpreted and applied. That is, if a value in the prior standard was only a rough guideline to be applied to specific industrial situations by experts familiar with the nature of the hazard and the reliability and precision of the data underlying the standard, OSHA cannot simply rely on a finding by one of its inspectors that the value specified in the standard was exceeded. It must show also that appropriate experts would consider the prior standard to be violated under the conditions at issue. This is not to say that the mere statement in a consensus standard that it was not intended as a legal standard should preclude its enforcement by OSHA. But, as its Associate Solicitor advised, the OSHA inquiry must be whether the adopted standard operationally proscribes conduct which would be permissible under the prior standard.

A somewhat related question is the legal effect of an OSHA standard promulgated under section 6(a) based on an improperly promulgated consensus standard or prior federal standard. As to consensus standards, the definition of "national consensus standard" in section 3(9) of the Act requires that promulgation have been under procedures by which interested and affected persons have reached agreement, that there have been opportunity for consideration of diverse views, and that consultation with other appropriate federal agencies have been undertaken. ${ }^{47}$ Failure to meet these criteria would appear to remove a standard from the definition of national consensus standard and thus preclude its promulgation under section $6(a) .{ }^{48}$ The effect of an OSHA standard adopted from an improperly promulgated prior federal standard is less clear. The definition of "established Federal

\footnotetext{
14 See Memorandum from Associate Solicitor for Occupational Safety and Health Mintz to Deputy Assistant Secretary Robbins on "Interpretation; 29 C.F.R. § 1910.94(b)(2)(i)" (July 9, 1973). 45 O.S.H.R.C. 1212 (1973).

${ }^{46}$ See, e.g., S.D. Mullins Co., 4 O.S.H.R.C. - (Oct. 24, 1973) (Commission opinion); Apex Paper Box Co., 4 O.S.H.R.C. - (Oct. 11, 1973) (Cleary, J., concurring); Buckeye Cellulose Corp., 4 O.S.H.R.C. 356 (1973); Bechtel Corp., 9 O.S.H.R.C. 762 (1973).

${ }^{47}$ Occ. Safety \& Health Act $\$ 3(9)$, 29 U.S.C. § 652(9) (1970).

${ }^{48}$ In Trojan Steel Co., - O.S.H.R.C. - Jan. 18, 1974) (in review), an OSHA standard was held improperly promulgated under section $6(a)$ of the Act because the version of the NFPA standard which OSHA purported to adopt was not in effect as a NFPA standard at the time of adoption. But Judge Kennedy held in Boise Cascade, - O.S.H.R.C. - (Feb. 12, 1973) (in review), that he was not empowered to rule on whether the Secretary had properly promulgated a standard. Judge Brenton in Tobacco River Lumber Co., - O.S.H.R.C. - (Dec. 20, 1973) (in review), properly rejected an attack on an OSHA standard based on an employer's argument that he personally had not participated in the development of the underlying consensus standard. Obviously, this differs from the valid objection that there generally was no opportunity to participate.
} 
standard" in section 3(10) of the Act ${ }^{49}$ does not contain explicit safeguards similar to those in the definitions of "national consensus standard." Perhaps the use of the term "established" in this definition is intended to cover this problem, and to preclude adoption under section 6(a) of improperly promulgated federal standards as not being "established" within the meaning of the definition. Such prior federal standards often are less widely known than consensus standards, since they applied prior to adoption under the Act only to those who dealt with the government. Thus, there was less opportunity for the parties now interested in them to oppose unreasonable requirements in them, and many employers who did not deal with the government have become subject to such standards although they had no opportunity to participate in their development. Under these circumstances, procedural regularity in the prior promulgation of established federal standards should be a minimum requirement for their adoption as OSHA standards.

As can be seen, the overriding difficulty with private standard development, and with prior federal standards as well, is that few, if any, of these standards were intended when developed for the role they now play as OSHA standards. In some cases this can be embodied in a legal objection to the OSHA standard or its interpretation; in many others it simply means that an inappropriate requirement, either too harsh or too lenient, has been imposed in the necessary, and necessarily hasty, effort to create a ready-made body of OSHA standards to begin enforcement under the Act.

\section{Developing New OSHA Standards}

\section{Agency Procedures}

Because it has already acquired a large, indigestible batch of standards originally developed as private or federal standards, OSHA has been relatively slow to utilize the permanent standard setting mechanism in section $6(\mathrm{~b})$ of the Act. ${ }^{50}$ There have been some standard setting proceedings started but they are too few and not far enough along in the process to allow a real judgment of the efficacy of the statutory procedure in producing good, workable standards.

The standard development process contemplated by the Act is a very flexible one. It provides for, but does not require, reference of scientific issues to NIOSH or use of an advisory committee, or both, before the Secretary proposes a standard. Section 7 (b) requires that members of advisory committees represent both employers and employees, and that the committees hold open meetings and make records of their deliberations available to the public.51 This use of advisory committees is a relatively new concept in standard making which may prove quite useful in resolving at least the scientific issues involved in standard development. The system of statutory deadlines for committee action and various subsequent steps of the standard promulgation process

\footnotetext{
${ }^{49}$ Occ. Safety \& Health Act \& 3(10), 29 U.S.C. \& 652(10) (1970).

${ }^{50}$ Id. $\S 6$ (b), 29 U.S.C. $\$ 655(\mathrm{~b})$.

${ }^{51}$ Id. $\$ 7$ (b), 29 U.S.C. $\$ 656(\mathrm{~b})$.
} 
in section 6(b) should insure that the use of committees will be more than a stalling tactic. ${ }^{22}$ It is hard to imagine very rigid judicial enforcement of these deadlines, however, unless it is apparent that there is no reasonable basis for delay. ${ }^{53}$

In the rulemaking procedure for promulgation of standards under section 6(b) of the Act, OSHA faces something of a dilemma. The statutory procedure is similar to informal rulemaking but with an oral hearing if requested by any interested person. It is not, as two reviewing courts have already pointed out, ${ }^{54}$ a formal rulemaking procedure on the record of the type to which a "substantial evidence" standard of judicial review is normally applied. In light of the type of "record" before the court (not only from the hearing but including written material submitted outside the hearing), and due to the presence of issues which are "legislative in character," the courts have been very reluctant to apply the "substantial evidence" standard required by the Act. 55 To alleviate this problem, OSHA has voluntarily moved in the direction of more formal proceedings (allowing cross-examination, employing a qualified administrative law judge, and keeping a verbatim transcript). At the same time, this more formal procedure undoubtedly has slowed promulgation of standards considerably from what would be possible with just the "legislative" type hearing. On balance, the agency has probably made the best compromise available to fit together the incompatible elements of the procedure provided by the Act.

The other standard making procedure available to OSHA is for "temporary emergency standards" under section 6(c) of the Act. ${ }^{56}$ Such standards may be promulgated without regard to the Administrative Procedure Act and may be made effective immediately upon publication in the Federal Register. But temporary emergency standards are only to be promulgated if employees are exposed to "grave danger" from a hazard, and a temporary emergency standard is necessary to protect.against the danger. They may be challenged judicially if there is not substantial evidence to support the Secretary's determinations that these requirements have been met.

The Fifth Circuit in the Florida Peach Growers case ${ }^{57}$ held that the requirement of "grave danger" means "a serious emergency" and the danger of "incurable, permanent or fatal" consequences to workers. In that case, involving exposure of agricultural workers to pesticides, it was held that the highly toxic nature of the pesticides did not in itself justify invocation of section 6(c) in light of very slim evidence that existing safeguards were inadequate or that workers were actually being harmed by the pesticides. The Peach Growers decision should have a salutary effect in discouraging excessive resort to section

52 Section 6(b)(1) generally requires an advisory committee to report to the Secretary within ninety days. Id. $\S 6(\mathrm{~b})(1), 29$ U.S.C. $\$ 655(\mathrm{~b})(1)$. The Secretary may set a different deadline, but not more than 270 days, for submission of committee recommendations.

${ }^{53}$ See AFL-CIO News, Feb. 9, 1974, at 6, reporting the mailing of a letter to OSHA criticizing the failure to adhere to the 270-day statutory limit.

${ }^{54}$ Industrial Union Dep't, AFL-CIO v. Hodgson, 499 F.2d at 472; Associated Indus. v. United States Dep't of Labor, 487 F.2d 342 (2d Cir. 1973).

"5s See id.

${ }^{58}$ Occ. Safety \& Health Act $\S 6(c), 29$ U.S.C. $\S 655(c)(1970)$.

57 Florida Peach Growers Ass'n v. United States Dep't of Labor, 489 F.2d 120 (5th Cir. 1974). 
6(c). Nonetheless, section 6 (c) will undoubtedly be the source of much future controversy and litigation. While situations meeting the statutory criterion of "grave danger" undoubtedly require prompt action, the issuance of standards wholly without procedural safeguards on a "crash" basis leaves much room for overreaction and institution of sweeping requirements without even understanding all the areas of potential applicability or the appropriateness of the promulgated requirements under widely differing industrial conditions. The difficulties encountered by OSHA with its first attempts to use section 6(c) apparently have alerted the agency to this problem. OSHA has developed the practice of making interim revisions of temporary emergency standards to correct unanticipated problems; ${ }^{58}$ and in considering the temporary emergency standard for vinyl chloride it held a hearing prior to promulgation of the standard. ${ }^{59}$ The agency is to be commended for taking these steps, even though not required to do so by the Act; they should help ameliorate the problems with this extraordinary procedure.

\section{Standard of Judicial Review}

As stated earlier, the Act sets forth a "substantial evidence" standard of judicial review for standard promulgation proceedings under section 6 . In light of the type of decisions which will have to be reviewed, however, and the "record" available to the courts to do so, the working inquiry is more likely to be whether the decision is arbitrary, irrational, or totally unsupported by any material of record. The lack of a conventional record and the consequent need to rely on materials "untested by anything approaching the adversary process" 60 is but one problem. In addition the issues involved range from the "highly technical" to those which are "legislative in character," either intrinsically or because the existing facts are too sparse to make a more reasoned decision. ${ }^{61}$

Two court decisions have thus far shed light on these problems. In the Associated Industries case, ${ }^{62}$ the OSHA standard for the number of lavatories in industrial workplaces was reviewed. The court, per Judge Friendly, held that the Secretary's action was arbitrary and not supported by substantial evidence; the agency failed to introduce any evidence at all at the hearing to support the requirement of the standard or to provide a rational explanation of its promulgation. The opinion indicated a clear reluctance to consider this type of issue, overcome only by the complete lack of support for the requirement. This certainly seems closer to a review for arbitrariness than a "substantial evidence" test although the court purported to apply that test.

The Industrial Union Department, AFL-CIO case ${ }^{63}$ involved review at the behest of organized labor of a number of decisions made by the Secretary

\footnotetext{
${ }^{58}$ See 38 Fed. Reg. 20,074 (1973), amending the temporary emergency standard on certain carcinogens.

${ }^{59}$ See 39 Fed. Reg. 12,342 (1974).

${ }^{60}$ Industrial Union Dep't, AFL-CIO v. Hodgson, 499 F.2d at 474.

${ }^{61}$ Id. at 474-75.

${ }^{62}$ Associated Indus. v. United States Dep't of Labor, 487 F.2d at 342.

63499 F.2d at 478 .
} 
in promulgating the asbestos standard. Judge McGowan started his opinion with an extended explanation of the difficulties of review, commenting favorably on the suggestion by the government that in such situations, courts should apply the substantial evidence test to issues susceptible of factual determination while using an "arbitrariness" or "irrationality" standard as to policy or political issues. The court's actual disposition of the issues in the case seems to follow this pattern, although not precisely. One determination of an essentially political character was accepted as "not irrational." A more scientific determination was upheld because it "although not compelled by the evidence, finds support in the record."64 Another determination was rejected because it was "neither explained nor readily apparent," essentially the reason given in the Associated Industries case. One matter was considered "within the range of the Secretary's discretion," and another was characterized as "non-arbitrary."

From the foregoing cases, it is apparent that only complete failure by the Secretary to support his decisions in the record or to articulate good reasons for them will result in judicial intervention in the standard making process. When the question boils down to conflicting evidence, the likelihood of overturning the Secretary's determinations is small. While the degree of review will turn on the state of the record and the nature of the issues involved, it probably will be considerably less than the "substantial evidence" review undertaken by the courts in formal rulemaking proceedings.

\section{Standard Development by the States}

Section 18 of the Act, the statutory bow to federalism, in addition to providing for state enforcement of federal standards, allows development by states of their own safety and health standards, largely independent of federal control. ${ }^{65}$ If there is no applicable federal standard, section 18(a) gives the states carte blanche in developing their own standards. Under section 18(c)(2) a state standard also may be developed to replace an existing federal standard covering the same hazard if it is "at least as effective" as the federal standard in protecting safety and health and does not "unduly" burden interstate commerce. No explicit provision is made in the Act to deal with a situation in which a federal standard is promulgated subsequent to development of a state standard under section 18(a), but presumably the state standard would be invalidated unless it met the requirements of section 18(c)(2). In any case, it is unclear who determines or reviews the adequacy of state standards promulgated in opposition to federal standards. The Act merely provides that the states submit a plan under which such standard activity may be carried out. There is no statutory provision for review of state-promulgated standards by OSHA subsequent to acceptance of a state plan. Theoretically, in an extreme case, approval of the state plan could be withdrawn, but this seems highly unlikely as a practical matter once approval of a state plan has been granted.

State developed standards, which may bear little similarity to federal stan-

${ }^{64} I d$, at 479 n.28.

${ }^{65}$ Occ. Safety \& Health Act $\S 18,29$ U.S.C. $\S 667$ (1970). 
dards or those developed by other states, are potentially very disruptive for multistate enterprises. It is difficult to say at this time how many states ultimately will enter the standard setting area, what sort of technical and scientific resources will be expended by different states for standard development, or whether many useful state standards will emerge. It is clear, however, that if there is significant independent standard making activity by states, serious problems will develop for employers with plants in different states. Those problems could be avoided, and the goals of federalism accomplished, through a different means of state involvement-such as state participation in the development of federal standards, which could then be applied uniformly throughout the country.

\section{II}

\section{Regulatory Control Through Standards}

\section{A. Interpretation and Variances by OSHA}

Interpretation of standards by OSHA must be distinguished from their formal interpretation by the Review Commission, which is part of the enforcement process under the Act. Informal interpretation by OSHA can be both a prosecutorial decision and a possible means of excepting persons and situations from the requirements of standards whose language seems literally to apply. To date OSHA's general position, at least publicly, has been to apply its standards as broadly as possible. Prosecutorial discretion, even in some extreme situations, has been exercised by charging a nonserious or de minimus violation rather than by ruling that the standard was not violated or did not apply. These are most unsatisfactory alternatives to a ruling of nonapplicability, however, because they leave in full force the statutory duty to abate violations, with potentially very heavy penalties for failure to do so.

This situation is aggravated because, if an informal interpretation is sought and OSHA's response is unfavorable, the agency has been made aware of what it considers a violation of the Act. The problem is most acute if the condition is one which must be observed in the workplace because an OSHA inspector is obligated under the Act to issue a citation for any violation he finds in inspecting a workplace. ${ }^{66}$ Thus it is foolhardy to invite OSHA to a workplace to observe the condition for which an interpretation is sought, although an observation is obviously often necessary to making a ruling. A relatively inflexible attitude by OSHA toward interpretation of standards also leads employers to seek the agency's opinion less frequently, relying instead on their own interpretation until challenged in an enforcement proceeding. To avoid the resulting reduction in voluntary compliance and increase in contested citations, the greatest possible use by the agency of interpretations or "clarifications" of the standards seems highly desirable.

Barring a favorable informal interpretation by OSHA, resort must be made to the statutory remedies of variance and standard amendment to gain exclu-

${ }^{68}$ See id. $\S 9(a), 29$ U.S.C. $\S 658($ a). This section states that the Secretary "shall . . . issue a citation" if he believes a violation of the Act has occurred. 
sion from the coverage of a standard. The Act provides for two separate types of variances in section $6(\mathrm{~b})(6)^{67}$ and section $6(\mathrm{~d}) .{ }^{68}$ The variance under section $6(b)(6)$ is only temporary, allowing deviation from standard requirements for no more than one year (plus two one-year renewals). This type of variance is really the same in substance as the abatement requirement in the statutory enforcement procedure set forth in sections $9^{69}$ and $10^{70}$ of the Act, except that technically the applicant has never been found in violation of the Act. The variances contemplated under section $6(\mathrm{~d})$ are permanent. They are only available, however, if conditions under the variance are "as safe and healthful" as under the standard. That is, a permanent variance is only available for conditions absolutely equivalent in employee protection to the standard. While a standard should not be whittled away by variances which destroy its effectiveness, this requirement for identical protection rather than, say, substantial equivalence seems unnecessarily harsh. ${ }^{71}$ Moreover, it seems incongruous that it is as high, and perhaps higher, than the requirement for amending the basic standard from which variance is sought.

The interrelationship of OSHA interpretations, variances, and standard amendments as ways to avoid an inappropriate standard requirement is a largely unresolved legal and administrative issue. While the variance route has been most popular to date in terms of number of applications made, relatively few variances have actually been granted. ${ }^{72}$ The processing of applications for variances by OSHA is complex and necessarily slow. Standard amendment proceedings, which involve a greater commitment of agency resources, have been even slower to progress. ${ }^{73}$ The resulting logjam can be broken only by greater use of informal interpretative rulings or "clarifications" by OSHA. Otherwise, there inevitably will be a greater emphasis on litigating standard issues before the Review Commission rather than seeking relief from OSHA.

\section{B. Enforcement Through Review Commission Proceedings}

The Occupational Safety and Health Review Commission is an independent federal agency, completely unrelated to the Department of Labor, which is charged with adjudicating most controversies over whether particular conditions in the workplace violate the Act. $^{74}$ It has no role in the promulgation of standards but a critical role in their interpretation and in compelling compliance with their requirements. Since the majority of the proceedings brought

${ }^{67} I d . \S 6(\mathrm{~b})(6), 29$ U.S.C. $\S 655(\mathrm{~b})(6)$.

${ }^{88} I d . \$ 6(\mathrm{~d}), 29$ U.S.C. $\$ 655(\mathrm{~d})$.

${ }^{69} I d . \$ 9,29$ U.S.C. $\$ 658$.

${ }^{70}$ Id. $\$ 10,29$ U.S.C. $\S 659$.

${ }^{71}$ It may be that in practice the Secretary does not require identical protection. See Bear Brand Hosiery Co. Variance, 39 Fed. Reg. 13,216 (1974) (exempting the applicant's "chain and sprocket arrangement" from a finding that "an employee's fingers may become lodged between the chain and sprocket with no harmful effect"); Chemico Metals Corp. Variance, id. at 16,198.

${ }^{72}$ As of March 31, 1974, only 21 variances had been finally granted of a total of 520 applications submitted. Occ. SAFETY \& Health Rep. 1486 (Apr. 25, 1974).

${ }_{73}$ OSHA reported that as of March 29,1974 , it had received 118 petitions for standard amendments, only three of which have progressed as far as being published as proposals for public comment. Id. at 1489 .

${ }^{74}$ See Occ. Safety \& Health Act $\$ \S 10,12,29$ U.S.C. $\$ \S 659,661$ (1970). 
before the Commission involve alleged standard violations, there is an already considerable body of decisions by the Commission and its administrative law judges on how standards are to be interpreted and enforced.

A number of major issues, however, remain unresolved or have been handled thus far in less than a definitive manner. Among these problems are the basic question whether the Commission can rule on the validity of standards, what nonstatutory defenses should be permitted as to standard violations, the problem of vague standards, the problem of choosing among several applicable requirements under the Act, and problems relating to the statutory abatement requirement.

\section{Commission Jurisdiction to Consider Validity of a Standard}

The question whether the validity of a standard can be challenged in an enforcement proceeding before the Commission is of fundamental importance. If a standard can be so attacked, this broadens dramatically the scope of the Commission's concern and in effect allows the Commission, in limited circumstances, to repeal or amend standards promulgated by OSHA under section 6 of the Act.

This is an issue which has arisen under many other federal statutes, often stated as whether regulations promulgated by the agency are "substantive" or merely "interpretative" rules. ${ }^{75}$ The competing considerations as to whether regulations are "substantive" generally are that substantive rules are more convenient for the enforcing agency because they allow it to narrow the case necessary to prove a violation. But substantive rules often fail in practical terms to provide interested parties an opportunity to participate in developing a requirement reasonable for their particular circumstances because the rule may be so broad, vague, or uncertain of application that general rulemaking procedures provide little protection. Allowing a challenge in an enforcement proceeding on a record containing concrete facts can be a valuable safeguard in this situation.

The issue of whether the Commission could examine the validity of standards was considered a number of times in the legislative history of the Act. That history, it is submitted, reflects a clear congressional decision that the Commission can and should consider the validity of the underlying standard during enforcement proceedings.

During Senate consideration of occupational safety and health legislative proposals in the 91st Congress (1969-70), three principal bills were considered: S. 2193, introduced by Senate Labor and Public Welfare Committee Chairman Williams, S. 2788, introduced by Senator Javits, and S. 4404, introduced by Senator Dominick. S. 2193 was the original bill to be introduced; S. 2788 and S. 4404 were offered as substitute versions. Both S. 2788 in section 8 and S. 4404 in section 13 provided that pre-enforcement judicial review of safety and health standards was to be the exclusive method of challenging the validity or reasonableness of a standard. ${ }^{76}$

${ }^{75}$ See, e.g., regulations under the Federal Food, Drug, and Cosmetic Act, 21 U.S.C. $\$ \$ 301-92$ (1970).

${ }^{76} \mathrm{~S} .2788$ in section $8(\mathrm{e})$ and S. 4404 in section 13(b) stated: "The remedy provided by this 
No comparable restriction appeared in S. 2193, the bill ultimately reported by the Senate Committee on Labor and Public Welfare. In discussing the question of review of standards, the Senate Report on S. 2193 states:

Section $6(f)$ provides that any person who may be adversely affected by a standard may, within 60 days of its issuance, seek judicial review in an appropriate United States court of appeals. While this would be the exclusive method for obtaining pre-enforcement judicial review of a standard, the provision does not foreclose an employer from challenging the validity of a standard during an enforcement proceeding. ${ }^{77}$

When the legislation reached the Senate floor, S. 4404 was offered as a substitute for S. 2193 and Senator Dominick, its sponsor, compared the standards review provisions of the two measures:

Both bills specifically provide for judicial review of standards. Under the committee bill, judicial review of standards is provided in the various U.S. courts of appeals. This right may be exercised up to 60 days after the standard is promulgated. The committee bill specifically provides that the filing for review not act as a stay of the standard, unless so ordered by the court.

The substitute bill, S. 4404, has a similar provision, for judicial review of standards, except the U.S. Court of Appeals for the District of Columbia is the only forum. Unlike the reported bill, this judicial review of standards is made an exclusive remedy. The time-period for review is 30 days after publication of the standard. Also, a petition for review would not stay the effect of a standard unless specifically so ordered by the court. ${ }^{78}$

During the same debate, Senator Williams, the sponsor of S. 2193, offered his own comparison of the two bills:

The bill as reported by the committee provides an opportunity for a person affected by the promulgation of a standard to seek judicial review within 60 days of the promulgation of such standard or the standard may also be challenged during an enforcement proceeding.

This is a very broad-scaled judicial review protection that completely meets any industry concerns regarding the ability to contest the standards in courts.

On the other hand, the substitute bill provides for exclusive judicial review within 30 days of the promulgation of a standard, and forecloses any possibility of obtaining judicial review of a standard in an enforcement proceeding. ${ }^{79}$

S. 2193 was passed by the Senate on November 17, 1970, the Senate having rejected the provision in S. 4404 which would have prevented challenges to standards during enforcement proceedings. ${ }^{80}$

In the House, several bills were considered by the Committee on Education and Labor. One of these, H.R. 13373 (a companion bill to S. 4404), introduced by Congressman Ayres, included language in section 8(e) limiting challenges of standards to pre-enforcement judicial review. However, no such provision appeared in H.R. 16785, the bill favorably reported by the Education and Labor Committee on July 9, 1970. In discussing procedures for enforcement of safety and health standards, which under this bill were enforced by

subsection for reviewing a standard shall be exclusive."

${ }^{77}$ S. REP. No. 91-1282, 91st Cong., Ist Sess. 8 (1970) (emphasis added).

${ }^{78} 116$ Cong. REC. 37,337 (1970) (emphasis added).

${ }^{79}$ Id. at 37,340 (emphasis added).

${ }^{80}$ Id. at 37,632 . 
the Secretary rather than a review commission, the House Report notes:

If an employer decides to contest a citation or penalty, or if the Secretary believes an employer has not corrected a violation within the prescribed period, the Secretary will afford an opportunity for a hearing governed by the Administrative Procedure Act. Based upon the hearing record, the Secretary shall issue an order confirming, denying or modifying the citation or penalty, or issue an order for the correction of the violation for which the citation was issued and for the assessment and collection of any penalty.

In these proceedings, the Secretary is to adjudicate, among other things, the validity of the standard, rule, order, or regulation alleged to have been violated and the reasonableness of the time permitted for the correction of the violation. ${ }^{81}$

On September 15, 1970, subsequent to the House Committee action, Representative Steiger introduced yet another occupational safety and health bill, H.R. 19200. The Steiger bill, which was offered to the House as a substitute for H.R. 16785 during debate on November 24, 1970, once again included in section 13(b) language limiting standard review to pre-enforcement proceedings. ${ }^{82}$ The House passed the Steiger bill, ${ }^{83}$ but the Conference version of the legislation, ultimately adopted by both Houses of Congress, omitted the language of the Steiger bill which would have prevented challenges to standards during enforcement proceedings. ${ }^{84}$

The congressional decision to eliminate the restrictive language of the House-passed version of the Act and thus to permit standard review during enforcement proceedings could not have been an oversight, particularly in view of the extensive consideration of this very issue during the debates and in the Committee reports. In addition, the Clean Air Amendments of $1970{ }^{85}$ passed by Congress only two days after the Act, contains language explicitly limiting the availability of standard review during enforcement proceedings. Section 307 (b) of the Clean Air Amendments ${ }^{86}$ provides in paragraph (1) that a petition for review of various actions under that Act must be filed within thirty days from the date of promulgation. It goes on to provide in paragraph (2) that "[a]ction of the Administrator with respect to which review could have been obtained under paragraph (1) shall not be subject to judicial review in civil or criminal proceedings for enforcement." 87 The distinction between these two contemporaneous pieces of legislation could hardly be clearer, or reflect more strongly a congressional intent not to preclude review of an OSHA standard in an enforcement proceeding.

Despite this overwhelming legislative history supporting Commission authority to consider the validity of standards, there is no clear indication that the Commission will follow this course. The Commission has not ruled directly on this issue and the Commission judges considering it have divided. Two early

\footnotetext{
${ }^{81}$ H.R. ReP. No. 91-1291, 91st Cong., 2d Sess. 24 (1970).

${ }^{82}$ See 116 Cong. Rec. 38,719 (1970).

${ }^{83} I d$. at 38,724 .

${ }^{84}$ See H.R. Rep. No. 91-1765, 91st Cong., 2d Sess. 16 (1970) (Conference Report on S. 2193).

${ }^{85}$ Pub. L. No. 91-604 (Dec. 31, 1970). The 1970 Amendments became part of the Clean Air Act, 42 U.S.C. $\$ 1857$ (1970).

${ }^{86} 42$ U.S.C. $\$ 1857 \mathrm{~h}-5(\mathrm{~b})(1970)$.

${ }^{87}$ Id.
} 
Commission judge decisions reached a negative conclusion without any reference to the legislative history of the Act. ${ }^{88}$ Two others held that the Commission could review the legal validity of standards. ${ }^{89}$ Judge Wienman in the Hormel case ${ }^{90}$ considered the legislative history at length and held:

The Congressional intent is eminently clear, and the result is sound. To foreclose employers from challenging the validity of standards during enforcement proceedings would place industry in the untenable position of being forced to prophesy all possible applications and constructions the Secretary of Labor might place upon the language of the multitudinous standards. Even more absurd, the Commission in a litigated enforcement proceeding might find itself ordering an employer to alter safe working conditions and expose workers to new hazards in order to satisfy the mandate of an inappropriate regulation.

We do not hold the Commission so powerless that it must act contrary to the spirit and intent of the Act. ${ }^{91}$

Judge Risteau in the Weyerhauser case ${ }^{92}$ not only held that the validity of a standard could be attacked in an enforcement proceeding, but went on to consider the validity of the standard at issue in that proceeding, and to uphold it.

However, Judge Kennedy in Boise Cascade ${ }^{93}$ also examined the legislative history in detail and reached a contrary result.

An examination of both the Act and its legislative history persuades me that I am not empowered to consider and determine the validity of a standard issued by the Secretary in connection with the adjudication of an alleged violation of the standard. While it appears that the validity of a standard is reviewable by the courts on judicial review of a Commission adjudication under Section 11 of the Act (contrary to the position taken by the Secretary), this question is not properly before me for decision and cannot be determined by me.94

It is difficult to understand Judge Kennedy's conclusion that the Commission and its judges may not consider the validity of a standard but a court reviewing a Commission decision can. Certainly, this would be troublesome as a practical matter since the court would have no record before it on this issue. Probably Judge Kennedy's decision and the other judges' decisions to the same effect reflect more a disquietude at the prospect of having to consider the issues underlying standards than an objective reading of the legislative history. In any case, quick clarification of this situation by the Commission or the courts seems imperative.

\section{Defenses to Standard Violations}

A variety of defenses to standard violations have been raised successfully in Commission proceedings. They reflect both the basic requirements of the Act and some policy determinations of the Review Commission and its judges. Initially, it may be noted that the burden of proof that a standard has been

\footnotetext{
${ }^{88}$ Diesel Constr. Co., 2 O.S.H.R.C. 595 (1973); McDevitt \& St. Co., 8 O.S.H.R.C. 8 (1972).

${ }^{89}$ Divesco Roofing \& Insulation Co., 4 O.S.H.R.C. 339 (1973); Joseph Bucheit \& Sons Co., 1 O.S.H.R.C. 609 (1973).

${ }^{90} 11$ O.S.H.R.C. - (Mar. 5, 1973).

91 Id. at - .

923 O.S.H.R.C. 994 (1973).

93 - O.S.H.R.C. - (Feb. 12, 1974) (in review).

94 Id. at - .
} 
violated is on the Secretary ${ }^{95}$ and a citation may be dismissed for simple failure to meet this burden. ${ }^{96}$ Commission decisions emphasize, moreover, that proof that an accident occurred is not enough; it must be shown that the specific requirements of a standard have been violated. ${ }^{97}$ Further, several Commission judges have held that a standard is not violated, despite failure to comply with its literal requirements, if no hazard existed as a result of such failure. ${ }^{98} \mathrm{Sim}$ ilarly, in a logical extension of the prior cases, it has been held that there is no violation if the standards requirements are not met but no employee of the employer cited was exposed to the hazard involved.99 Parenthetically, it may be noted that exposure of employees of a particular employer is a statutory requirement for violation of the general duty clause since the employer owes the duty to "his employees." There does not appear to be any such limitation written in the Act as to standards, but this deficiency has been remedied by the Commission. ${ }^{100}$

Another group of defenses cluster around the general idea that compliance with standards cannot be required if it would be impossible, ${ }^{101}$ or impractical and "unreasonably harsh." ${ }^{102}$ An important ruling along these lines is the Industrial Steel Erectors case, ${ }^{103}$ a Commission decision which recognizes as a defense a showing that the conditions cited are safer than those which would result from compliance with the standard. The statutory abatement requirement has generated a variation on the "impossibility" defense. It has been held that the Secretary has the burden of proving that abatement of the hazard is feasible. ${ }^{104}$ In other words, a situation may violate the literal requirements of the standard and be hazardous, but it is not a violation unless the Secretary can demonstrate that it is possible to meet the standard or eliminate the hazard in the particular workplace at issue. Similarly, failure to abate within a given time is no violation if conditions made it impossible to comply with the deadline. ${ }^{105}$

A common feature of many of these defenses is that they represent a tacit assumption of jurisdiction to consider the validity of the standard at issue, at

\footnotetext{
${ }^{95}$ See, e.g., Collyer Associates, Inc., 2 O.S.H.R.C. 230 (1972).

${ }^{96} \mathrm{See}$, e.g., Equity Supply Co., 2 O.S.H.R.C. 245 (1972).

${ }^{97}$ See, e.g., Koppers Co., 1 O.S.H.R.C. 666 (1972). The nature of the violation must be pleaded with particularity as well. See Union Camp Corp., 5 O.S.H.R.C. 514 (1973).

${ }_{98}$ Mesa Fiberglass Prods. Co., 3 O.S.H.R.C. 784 (1973); Zenith Radio Corp., 6 O.S.H.R.C. 214 (1973); Ashland Oil, Inc., 5 O.S.H.R.C. 631 (1973).

${ }^{99}$ City Wide Tuckpointing Serv. Co., 3 O.S.H.R.C. 194 (1973) (Commission decision); Martin Iron Works, Inc., 9 O.S.H.R.C. 695 (1972); J.E. Roupp \& Co., 7 O.S.H.R.C. 914 (1972).

${ }^{100}$ See Address by Robert D. Moran, Chairman, Occupational Safety and Health Review Commission, Apr. 17, 1974, stating that "[d]uty under the Act runs from an employer to his own employees-not somebody else's." (Emphasis in original.)

101 See W.C. Sivers Co., 8 O.S.H.R.C. 480 (1972).

${ }^{102}$ See Masonry, Inc., 5 O.S.H.R.C. 524 (1972).

${ }^{103} 6$ O.S.H.R.C. 154 (1974); accord, American Bridge, Div. of U.S. Steel Corp., 12 O.S.H.R.C. - (Oct. 2, 1974).

${ }^{104}$ See National Realty \& Constr. Co. v. Occupational Safety \& Health Review Comm'n, 489 F.2d 1257, 1268 (D.C. Cir. 1973); Getter Trucking, Inc., 7 O.S.H.R.C. 1284 (1974); Paccar, Inc., - O.S.H.R.C. - (Feb. 15, 1974) (in review); Anchor Hocking Corp., - O.S.H.R.C. - (Feb. 14, 1974) (in review); Consolidated Installations Corp., 9 O.S.H.R.C. 562 (1974).

${ }^{105}$ Forrest Lumber Co., 4 O.S.H.R.C. - (Aug. 22, 1973).
} 
least in the particular circumstances and sometimes generally. Often this is combined with a denial that the validity of the standard can or should be determined by the Review Commission. In Industrial Steel Erectors, for example, Commissioner Cleary states:

This is not to say that the standards adopted by the Secretary are not substantive rules having the force and effect of law. But in our view an exception to the requirement of section $5(\mathrm{a})(2)$ and section $5(\mathrm{~b})$ themselves must be implied to permit a condition of greater safety or health to prevail in the workplace than is possible under a standard that has general application. ${ }^{106}$

Perhaps it is possible to imply such an exception to the absolute words of the Act but it would seem much less strained simply to say that the standard was held invalid in the particular circumstances because it detracted from, rather than improved, the safety of the workplace.

The final defense considered here involves reliance on an OSHA interpretation of a standard, which OSHA later repudiated. In the Koppers case ${ }^{107}$ OSHA had issued a directive to the industry stating that utilization of certain specified protective measures would constitute compliance with the standard. The employees were cited for violation of the standard and pleaded that they were complying with the OSHA directive, and that OSHA was estopped from taking a contrary position as to what constituted compliance with the standard. Judge Chapplin held this to be a valid defense and dismissed the citations. This defense is certainly a reasonable one in terms of equity and of practical administration, even if it is not compelled by the Act.

\section{Vagueness of Standards}

One additional defense recognized by the Commission and its judges, that a standard may be unenforceably and perhaps unconstitutionally vague, requires separate consideration. First, it is certainly possible to have an occupational safety or health standard which is unreasonably vague. For example, one presently effective standard provides that "no contractor or subcontractor ... shall require any laborer or mechanic ... to work in surroundings or under working conditions which are ... hazardous ... or dangerous to his health or safety."108 The quoted language gives no guidance whatever to the employer regarding how to comply. Most employers, if they realized that their workplace was "hazardous" or "dangerous to ... health," would already have taken steps to remedy the unsafe conditions. Also, the quoted language does not really contain any independent legal requirement as its operative language is virtually the same in effect as the general duty clause.

Certainly, a standard of the type described above is unenforceable and should be declared void for vagueness. Enforcing such a standard against an employer would violate constitutional requirements of due process. ${ }^{109}$

${ }^{106} 6$ O.S.H.R.C. at 157.

${ }^{107}$ - O.S.H.R.C. - (Feb. 19, 1974) (in review).

10829 C.F.R. \& 1926.20(a)(1) (1973).

${ }^{100}$ See Boyce Motor Lines, Inc. v. United States, 342 U.S. 337 (1952); United States v. Petrillo, 332 U.S. 1 (1947); Connally v. General Constr. Co., 269 U.S. 385 (1926). 
This is most clearly true in a criminal proceeding because the leading cases all relate to criminal violations. Thus, criminal prosecution for violation of standards under section 17 (e) of the Act ${ }^{110}$ certainly would be subject to a defense that the standard at issue was void for vagueness. ${ }^{111}$ While this defense may not apply with full vigor to civil penalty actions before the Commission, there is no logical reason why someone should be subject to even a civil penalty for violation of a completely unintelligible requirement. ${ }^{112}$

While standards may thus be void for vagueness, this defense has attained a popularity in Review Commission and Commission judge decisions far beyond what appears to be necessary. ${ }^{113}$ Despite the broad statutory mandate and the remedial purpose of standards, the theory seems to have developed

${ }^{110}$ Occ. Safety \& Health Act § 17(e), 29 U.S.C. § 666(e) (1970).

${ }^{111}$ See Winters v. New York, 333 U.S. 507 (1947).

112 There is also the argument that the "civil penalties" under the Act are in reality criminal sanctions, which would make the higher standard for criminal violations applicable here as well. See Lipke v. Lederer, 259 U.S. 557, 559 (1922); Wing Wong v. United States, 163 U.S. 228, 237 (1896). See also Charney, The Need for Constitutional Protections for Defendants in Civil Penally Cases, 59 Cornell L. Rev. 478 (1974).

${ }^{113}$ Two standards have been the subject of much Review Commission controversy as to whether they are unenforceably vague. In Santa Fe Trail, 5 O.S.H.R.C. 840 (1973), a divided Commission (with Commissioner Cleary dissenting) held that the requirement that a workplace be in "near proximity" to a medical facility or have personnel trained in first aid is too vague. In Ryder Truck Lines, 4 O.S.H.R.C. - (Feb. 27, 1973), the Commission, over a vigorous dissent by Chairman Moran, upheld as enforceable the following requirement:

Protective equipment, including personal protective equipment for eyes, face, head, and extremities, protective clothing, respiratory devices, and protective shields ánd barriers, shall be provided, used, and maintained in a sanitary and reliable condition wherever it is necessary by reason of hazards of processes or environment, chemical hazards, radiological hazards, or mechanical irritants encountered in a manner capable of causing injury or impairment in the function of any part of the body through absorption, inhalation or physical contact.

29 C.F.R. $\$ 1910.132(a)$ (1973).

Two separate courts of appeal also have recently upheld this standard against a vagueness claim. See Ryder Truck Lines v. Brennan, - F.2d - (5th Cir. 1974); McLean Trucking Co. v. Occupational Safety \& Health Review Comm'n, - F.2d - (4th Cir. 1974). Initially, it is hard to see why the Commission invalidated a relatively narrow requirement in the first aid standard containing the obvious and beneficial remedy of simply providing trained first aid personnel while upholding the much broader and more amorphous requirement of the protective equipment standard. The rationale given by the Commission in Modern Automotive Serv., 5 O.S.H.R.C. 738 (1974), that other regulations and "workplace customs" illuminate the meaning of the protective equipment standard, is not satisfying. Except where it is merely duplicative of other regulations, the Commission thus has justified this standard based solely on "customary practices." While the words of the standard are not necessarily too vague, this substitution of "custom" clearly is worse.

Looking simply to their language, neither the first aid standard nor the protective equipment standard should be invalidated for vagueness. Both provide significant direction to employers and are capable of being understood and followed by men of reasonable intelligence although each, admittedly, could be written in more precise terms. The difficulty with using more detailed requirements, however, must also be recognized. Consider the "near proximity" requirement in the first aid standard. Ordinarily $\mathbf{5 0 0}$ yards would probably satisfy this requirement as it could be quickly covered, even on foot, in an emergency. But what if the 500 yards were across a deep, rapid river and there was no bridge for 20 miles in either direction? Obviously, the answer is not to require more precise standards but to interpret the present ones in a reasonable manner in light of their lack of precision. In Cooper Laboratories, Inc. v. Commissioner, Federal Food \& Drug Administration, - F.2d - , - (D.C. Cir. 1974), Judge Wright observed: "Even a relatively precise regulation may create a small zone of ambiguity, and a [particular situation] may fall into that zone. By the same token, a regulatory provision which seems vague in the abstract may nonetheless be conclusively at odds with a peculiarly deficient [situation]." 
that a standard must be like a cookbook recipe, specifying the precise circumstances which may be hazardous and step-by-step directions for abatement. While such precision is certainly desirable to the extent it can be attained, it is not the benchmark against which statutory standards should be measured for vagueness.

The basic inquiry in determining whether a standard is void for vagueness should be whether it focuses the employer's attention in a meaningful way on particular hazards or on the proper methods of remedying specific hazards. A standard is not too vague simply because a conscientious employer could interpret it more broadly or narrowly than it might ultimately be interpreted by the courts. Considering the widely varied nature of hazards in the industrial workplace, it is justifiable that a standard may suggest somewhat more than minimal compliance to the employer. This is not to say that the Review Commission should not be concerned about the unfairness to employers in applying such standards. But the inquiry should be whether the employer's interpretation of the standard was reasonable, not whether the language of the standard might be stretched to an unreasonable extent in no way related to particular conditions at issue. For example, it should be considered whether the claimed hazard was a realistic danger in the particular workplace or, if allegedly inadequate protective measures were taken, whether such measures were reasonable in light of the extent of danger in the particular workplace.

This type of approach has the benefit of leaving the standard in effect to be enforced against the employer who has taken no real steps to comply. The Commission's invalidation of standards for vagueness has the peculiar effect of declaring a standard void for vagueness because it does not specify a method of protection in cases where the employer has provided no protection of any kind. The suggested approach, on the other hand, will exonerate an employer who has provided reasonable protective measures without letting a completely irresponsible employer escape. If OSHA believes that a method of protection other than that approved by the Commission should have been used, it has the option of specifying that method for the future in an amended standard.

The suggested approach was taken by Judge Burroughs in the Rentenbach Engineering case. ${ }^{114}$ OSHA alleged violation of a standard requiring pipe supports to be designed for 100 per cent overload but not specifying any particular manner or type of support. OSHA urged that the method of support adopted by the employer did not satisfy the standard. Noting that the standard was "vague and general in its intent," Judge Burroughs concluded that "[i]n view of the nebulous factors on which [the employer] had to predicate its actions, fairness dictates that it be judged on the issue solely as to whether its interpretation of the pipe support requirement was reasonable under the applicable facts." 115 It is submitted that this general inquiry will work equally well for any other standard which is really not so vague as to be completely unintelligible, and that a finding that a standard is void for vagueness should be used only as a last resort.

1141 O.S.H.R.C. 1033 (1972).

${ }^{115} \mathrm{Id}$. at 1046. 


\section{Choosing Among Applicable Requirements Under the Act}

- Another problem in enforcing standards is choosing among applicable requirements which may bear on a particular hazardous condition in a workplace. That is, a particular condition may be potentially subject to several standards, both general and specific, and may also be within the coverage of the statutory general duty clause. How does the employer determine which requirements apply? How does OSHA decide which rule to refer to in its citation if the condition is uncorrected despite apparent multiple violations?

The Act does not answer these questions. On its face, section 5(a) ${ }^{116}$ appears to hold the employer subject to both the general duty clause and all applicable standards. However, the legislative history is clear that primary reliance is to be placed on standards rather than the general duty clause. ${ }^{117}$ From this it follows that the general duty clause should not be invoked if a standard applies. OSHA has so provided in its regulation that compliance with an applicable standard shall be deemed compliance with the general duty clause. ${ }^{118}$ As a matter of general logic, and consistent with a well-recognized principle of statutory construction, ${ }^{119}$ it also follows that compliance should be measured against the most specific standard applicable to a particular situation. Again, OSHA regulations so provide. ${ }^{120}$

The difficulty comes in applying these principles if it is uncertain whether a standard applies to a given condition in a workplace, or which of several standards of varying application and specificity apply to such condition. There have been a number of problems of this type in Review Commission cases. In Sun Shipbuilding ${ }^{121}$ OSHA cited the employer under both the general duty clause and a specific standard as to the same condition. The Commission affirmed the standard violation and, because the standard applied, dismissed the general duty charge. Commissioner Cleary concurred, but stated that OSHA should be permitted, and indeed encouraged, to plead in the alternative. In Advance Air Conditioning ${ }^{122}$ the employer was cited only for violation of the general duty clause. The Commission found, however, that the conditions at issue violated a standard and, ruling that the employer was not prejudiced thereby, held that the employer was in violation of the standard rather than the general duty clause. In several other cases ${ }^{123}$ the Commission held that the standard cited had not been violated and, because the general duty clause was not cited, its violation could not be considered. Commissioner Cleary dissented in each case, urging that the pleadings should be conformed to the evidence and, in any event, that OSHA should utilize alternative pleading.

\footnotetext{
${ }^{116}$ Occ. Safety \& Health Act $\S 5(a), 29$ U.S.C. $\$ 654(a)$ (1970).

117 See, e.g., S. REP. No. 91-1282, 91st Cong., 2d Sess. 10 (1970).

11829 C.F.R. § 1910.5(f) (1973).

${ }^{119}$ Fourco Glass Co. v. Transmirra Prods. Corp., 353 U.S. 222, 229 (1957); Ginsberg \& Sons v. Popkin, 285 U.S. 204 (1932).

12029 C.F.R. $\$ 1910.5$ (c)(1) (1973).

121 4O.S.H.R.C. - (Oct. 3, 1973); accord, Harvey Wrecking Co., 5 O.S.H.R.C. 147(1973).

122 - O.S.H.R.C. - (1974). In Copelan Plumbing Co., 9 O.S.H.R.C. 415 (1974), the Commission upheld, over Chairman Moran's dissent, a violation based on a different standard than the one cited, stating that the issue of violating the uncited standard was tried "by consent of the parties."

${ }^{123}$ B. Heckerman Iron Works, Inc., 3 O.S.H.R.C. 1165 (1973); Gressani-Gysel Constr., Inc., -
} 
Similar difficulties have arisen in cases involving conflicts between standards. In Collier Construction, ${ }^{124}$ OSHA charged violation of a general standard but Judge Gold found a more specific standard applied, with which the employer was in compliance. More questionable results were obtained in Basic Rock Products $^{125}$ and Brown-Jordan Company. ${ }^{126}$ In the former, the judge found OSHA had cited an inapplicable specific standard and not the general standard which applied; in the latter, the general standard was cited, but not a specific standard held to be applicable. In both cases no violation was found although there is at least the implication that the uncited standard had been violated.

While a total solution to this problem probably is not possible in light of the number and complexity of statutory standards, adoption of Commissioner Cleary's suggestion of alternative pleading certainly would minimize the difficulty. This would prevent the cases in which the employer has clearly violated the Act in one way or another but escapes without penalty simply because the Review Commission does not agree with OSHA's choice of violation. Also, the employer would be put on notice of all possible violations for which he is accountable and could prepare his defense accordingly. Of course, the final result should be a single violation and a single penalty for any given violative condition, no matter how many alternative ways it was pleaded to violate the Act.

\section{Abatement Problems}

A final legal difficulty with Commission enforcement of standards relates to the statutory abatement requirement. Section 17(d) of the Act provides a penalty of up to $\$ 1,000$ for each day that a violation remains uncorrected after the final order of the Review Commission finding the violation becomes effective. ${ }^{127}$ The problem is that in some situations it is uncertain that the allegedly violative condition can be corrected, or can be corrected sufficiently to meet the requirements of the standard. Since the purpose of the Act is to correct those conditions which are susceptible to correction and not to punish for failure to do the impossible, the feasibility of making the correction is very relevant to whether the Act has been violated at all.

An example of this problem might involve one of the air contaminant standards specifying $\mathrm{X}$ milligrams of contaminant of air per cubic meter as the highest exposure allowed. ${ }^{128}$ The standard requires engineering or administrative controls to avoid exceeding this level or, if neither is feasible, the use of personal protective equipment to protect employees from excessive exposure. In considering whether engineering controls are feasible, the evidence may show that the best engineering experts are unable to predict whether sufficient control can be achieved. The state of the art is such that the best drawn plans may not work to reduce the level of contamination to below $\mathrm{X}$ milligrams although

O.S.H.R.C. - (July 30, 1973); Bi-Co Pavers, Inc., 5 O.S.H.R.C. 472 (1973).

${ }^{124} 6$ O.S.H.R.C. 491 (1974).

1252 O.S.H.R.C. $1164(1973)$.

1267 O.S.H.R.C. 25 (1974).

127 Occ. Safety \& Health Act $\$ 17($ a), 29 U.S.C. $\$ 666$ (a) (1970).

${ }^{128} 29$ C.F.R. $\$ 1910.93$ (1973). 
they will definitely have some beneficial effect. Under these circumstances the employer is put in an impossible situation if he is found in violation of the Act. Assuming that he made his best efforts to abate but they turn out to be unsuccessful, the employer is subject to a $\$ 1,000$ per day abatement penalty, the same as if he had made no effort to abate at all.

It does not appear that a Review Commission order under section 10(c) ${ }^{129}$ that a condition violates the Act can be withdrawn based on subsequent experience showing that abatement cannot be achieved as had been contemplated when the violation was found. ${ }^{130}$ Thus, while a plea of good faith attempt to comply might be offered to counter imposition of the penalty for failure to abate, the employer is left with no adequate legal defense for his failure to do the impossible. It is suggested that the Review Commission and its judges bear this situation in mind and impose on OSHA a heavy burden to show that abatement is in fact achievable in order to establish violation of the Act. ${ }^{131}$

\section{State Enforcement of Standards}

It is beyond the scope of this article to deal with the overall merits of enforcing the Act through state plans rather than through a unified federal effort. ${ }^{132}$ However, any consideration of the legal problems of standards under the Act cannot fail to consider the effects of this enforcement scheme.

The fundamental problem, so far as standards are concerned, is that standards by their nature are intended to be uniform rules to be applied equally to all applicable workplaces. They are only fair and reasonable to the extent that each workplace of each employer is judged equally depending upon the conditions found there. While there is nothing inherent in enforcement through state plans which prevents such uniformity, the general diffusion of authority to set, interpret, exempt from, and enforce standards creates innumerable possibilities for nonuniform application of standards.

The difficulties created by state promulgation of entirely separate standards was mentioned earlier in this article. ${ }^{133}$ Even more troubling, however, are the remaining state activities in which differences may arise. The most formal, and thus the easiest of these to deal with, is the matter of variances. When a federal standard has been adopted as a state standard under a state plan and ultimately becomes enforceable only by the state pursuant to section 18(e) of the Act, ${ }^{134}$ it obviously will be necessary for the state to be able to grant variances as to that standard. State plans typically include authority to do so. In this

\footnotetext{
${ }^{129}$ Occ. Safety \& Health Act $\S 10(c), 29$ U.S.C. $\$ 659$ (c) (1970).

${ }^{130}$ The recent Commission decision in York Metal Finishing Co., 7 O.S.H.R.C. 845 (1974), however, held that the validity of an original uncontested citation could be challenged in an action for failure to abate. Perhaps the same rationale would allow relitigation of the feasibility of abatement based on subsequent experience.

131 For decisions holding that the Secretary must prove that abatement is feasible, see cases cited in note 104 supra.

${ }^{132}$ For -a favorable view of state plans, see Brown, State Plans Under the Occupational Safely and Health Act of 1970, 38 LAw \& ConTEMP. Рrob. 745 (1974).

${ }^{133}$ See Part I, D supra.

${ }^{134}$ Occ. Safety \& Health Act § 18(e), 29 U.S.C. § 667(e) (1970).
} 
situation questions arise about state recognition of federal variances and, conversely, about the possibility of state-granted variances which erode away the heart of the federal standard.

OSHA has published a rulemaking proposal dealing with federal and state variances from identical standards ${ }^{135}$ which may resolve some of these problems, but also raises additional questions. The proposal provides for mutual recognition by OSHA and by the state of variances granted by the other authority. In the case of a federally granted variance, all states under standards identical to the federal standard presumably would be required to recognize the federal variance. The proposed rule is unclear as to the extent of federal recognition of a state-granted variance. Certainly, it would apply as to any federal enforcement in the state granting the variance. But would it also be federally recognized in other states? And would the other states also be forced to recognize the variance granted by the first state for their own enforcement purposes? The proposal, to eliminate "forum-shopping," forbids applying for variances both to OSHA and to the state. It does not appear to forbid a multistate employer from seeking variances from more than one state. Assuming this is done and the results vary, which result will OSHA recognize?

Beyond the problems of completely different standards and different results due to variance authority, lie the real problems dealing with everyday interpretation and enforcement of standards. It is hard enough for the federal government operating under unified authority to achieve a reasonable degree of consistency in the application of legal requirements across the country. How can such consistency be achieved when the only common links are the printed words of the standards, with all their ambiguities, the tenuous system of "monitoring"136 and reports ${ }^{137}$ from the states to OSHA, and visits to the states every six months by OSHA representatives? ${ }^{138}$ Not only do different state governments reflect different attitudes toward labor and management but they operate through different forms of organization and use different enforcement mechanisms, all with their own biases. Even to the extent that the state authorities accept the concept of uniformity and the validity of precedents from other jurisdictions, there will be great difficulty in finding the relevant precedents and rulings due to their diverse forms and to the lack of any central coordination or compilation of such rulings.

Based on these difficulties-and the expectation that others will develop as the system comes into operation-it is difficult not to predict that the state plan system will lead to complete chaos in the application of standards. This may be an overly pessimistic view in that more standardization of approach and more coordination of efforts through OSHA or employer associations and unions may ultimately develop. Even granting this possibility, however, the justification for the state plan system in the standards area and the possible benefits it offers compared to a uniform federal system of developing and enforcing standards are difficult to discern.

\footnotetext{
13539 Fed. Reg. 12,141 (1974).

${ }^{136}$ See 29 C.F.R. § 1954.2, as promulgated in 39 Fed. Reg. 1837-39 (1974).

${ }^{137}$ See id. \$ 1954.10.

${ }^{138}$ See id. \$ 1954.11.
} 


\section{Conflicts With Other Legal Requirements}

The possibility that standards promulgated under the Act may conflict with other legal requirements promulgated under other federal laws also raises interesting legal and policy questions. Basically, the conflicts fall into two categories-those with requirements of other federal agencies and state agencies acting under federal authority "affecting occupational safety or health," covered by section $4(\mathrm{~b})(1)$ of the Act; ${ }^{139}$ and all other conflicts, dealt with to a limited extent by section $4(b)(3)$ of the Act. ${ }^{140}$

\section{Section $4(b)(1)$}

Section $4(\mathrm{~b})(1)$ is jurisdictional; it provides that the Act does not apply at all to "working conditions" of employees as to which other agencies "exercise statutory authority" to prescribe or enforce standards affecting occupational safety or health. One problem here is the scope of the term "working conditions." Does a federal regulation covering some working conditions divest OSHA of jurisdiction over other working conditions of the same employees or in the same workplace? Such a broad construction would seem unreasonable and has been rejected in a series of Commission decisions which applied section 4(b)(1) where another federal agency had issued regulations affecting occupational safety and health, but only to the extent that such regulations actually regulated the specific working conditions involved. ${ }^{141}$ In Lovell Clay Products, ${ }^{142}$ for example, Judge Winters concluded that certain items in the citation were the subject of regulations under the Mine Safety Act and thus covered by section 4(b)(1), while other working conditions specified in the citation were not.

Another question under section 4(b)(1) which apparently has not yet been litigated is the meaning of "exercise statutory authority." All the cases so far have involved conditions as to which the other agency had issued regulations. But suppose the other agency has authority to issue such regulations but has not done so. Could OSHA exercise jurisdiction in the meantime? Also, could OSHA claim that the regulations of the other agency were so inadequate as to not constitute an exercise of statutory authority? Or suppose the other agency has an entirely adequate regulation but is not enforcing it?

The greatest difficulty with section $4(b)(1)$ is the meaning of the word "affecting" in the requirement that the conflicting regulations must be ones "affecting occupational safety or health." There is no problem with regulations under other federal laws designed specifically to protect employees in particular industries such as the transportation and mine safety laws. But what about laws designed primarily for some other purpose under which regulations are issued that have some effect on occupational safety or health?

This issue was faced squarely in the recent Review Commission decision

${ }^{139}$ Occ. Safety \& Health Act $\& 4(b)(1), 29$ U.S.C. $\$ 653(b)(1)$ (1970).

${ }^{140} I d . \S 4(\mathrm{~b})(3), 29$ U.S.C. $\S 653(\mathrm{~b})(3)$.

${ }^{141}$ See Bettendorf Terminal Co., 8 O.S.H.R.C. 343 (1973); Penn Cent. Transp. Co., -O.S.H.R.C. - (Jan. 29, 1973); Lovell Clay Prods., 10 O.S.H.R.C. 237 (1973); Phoenix, Inc.-Legore Quarries

Div., 1 O.S.H.R.C. 335 (1972).

${ }_{142} 10$ O.S.H.R.C. 237 (1973). 
in Fineberg Packing Co. ${ }^{143}$ In that case the Department of Agriculture specified in regulations issued under the Wholesome Meat Act that washrooms and other sanitary facilities must be provided and maintained in a clean and sanitary condition. Fineberg Packing Company was charged with violation of an OSHA standard with strikingly similar wording ${ }^{144}$ when the OSHA inspector found that an employee change room was "partially littered with clothing, socks and loose toilet paper and ... malodorous." ${ }^{145}$ Judge Harris held that the USDA regulations required invocation of section 4(b)(1):

The Department of Agriculture, another Federal agency, has exercised its statutory authority to prescribe standards affecting the safety and health aspects of specified working conditions of employees and has promulgated standards which affect working conditions which are the subject of the within citation. It was the intention of the Congress to cover all working conditions of employees insofar as possible, however, it was not its intention to subject an employer to dual or divided governmental authority and control of such employee working conditions and under the provisions of Section 4(b)(1) of the Act nothing in the said Act can be applied to the working conditions herein with respect to which the Secretary of Agriculture has exercised his authority. ${ }^{146}$

Judge Harris' reasoning seems entirely valid with regard to the problems of divided governmental authority. This result also satisfies the well established legal principle that if two statutes cover the same subject matter they should be applied, if possible, to give effect to both statutes. ${ }^{147}$ Thus, the most acceptable holding is that section 4(b)(1) applies and prevents the Department of Labor regulations from conflicting directly with the USDA regulations. The only unsatisfying aspect of this result is that the USDA regulations, as well as the OSHA standard (but for section 4(b)(1)), were apparently violated and, so far as the record shows, the employer suffered no penalty.

The Review Commission reversed Judge Harris in Fineberg Packing Co. in an opinion by Commissioner Cleary stating that the USDA regulations should not be viewed as "affecting" occupational safety or health because their effect on employee safety and health was "incidental" to their main purpose of protecting consumers of products regulated by the Wholesome Meat Act. The test given for coverage under section $4(\mathrm{~b})(1)$ was:

To be cognizable under section 4(b)(1), we conclude that a different statutory scheme and rules thereunder must have a policy or purpose that is consonant with that of the Occupational Safety and Health Act. That is, there must be a policy or purpose to include employees in the class of persons to be protected thereunder. This interpretation of section $4(\mathrm{~b})(1)$ appears more reasonable than the rather literal interpretation of the section applied by the Judge that would recognize any and all rules of other agencies having a benign but fortuitous effect on job safety or health, and therefore to be the more likely choice of the Congress. ${ }^{148}$

1437 O.S.H.R.C. 405 (1974).

144 Compare 9 C.F.R. $\$ \S 308.4,308.7$ (1974), with 29 C.F.R. $\S 1910.141$ (a) (1973).

145 Fineberg Packing Co., 7 O.S.H.R.C. 405, 417 (1974).

${ }^{146}$ Id. at 422 .

${ }^{147}$ See, e.g., United States v. Borden, 308 U.S. 188, 189 (1939); Rawls v. United States, 331

F.2d 21, 28 (8th Cir. 1964).

1487 O.S.H.R.C. at 407. 
Chairman Moran dissented for essentially the reasons given by Judge Harris. A final decision on this important issue obviously must come from the courts.

\section{Section $4(b)(3)$}

Despite the undeniable importance of effecting improved occupational safety and health to the greatest extent possible, this objective must be viewed in conjunction with other important governmental policies whose requirements may conflict with the attainment of the objectives of the Act. Section 4(b)(3) of the Act, particularly its recognition of the need to "achieve coordination" between the Act and other federal laws, suggests congressional recognition of this principle.

Problems of this sort already are appearing in Commission cases. In Otis Elevator Co. ${ }^{149}$ for example, Judge Chalk upheld the reasonableness of a proposed method of abatement of a violation of the Act on the ground that a suggested superior method of abatement could not be carried out because it would involve increased consumption of natural gas at a time when such gas was critically in short supply in the area. ${ }^{150}$

The difficulty with section $4(\mathrm{~b})(3)$ is that it merely requires OSHA to report to Congress at some future date; it is not a viable defense under the Act. The proper rule would appear to be that the objectives of the OSHA regulation and their importance in the particular circumstances at issue should be weighed against conflicting considerations of national policy embodied in other statutes and their relative importance in the particular circumstances. Such a view presumably underlay Judge Chalk's decision in Otis Elevator Co. although it is not articulated in the opinion in that case.

\section{CONCLUSTON}

While this article has suggested numerous legal difficulties with the promulgation and enforcement of mandatory occupational safety and health standards, the use of such standards should nevertheless be pursued to the maximum extent possible. In the absence of standards, reliance must be placed on the Act's general duty clause, under which the employer is given no guidance on how to protect his workers and no opportunity prior to an enforcement proceeding to protest an OSHA requirement or to help shape it to meet the needs of his workplace. Standards, however imprecise, do provide some guidance to employers as to how to make their workplaces safe and healthful and do allow the level of health and safety in the workplace to be raised above the minimum level required by the general duty clause. ${ }^{151}$

There are also a number of issues regarding standards which are nonlegal in nature and thus beyond the scope of this article. For example, Review Com-

\footnotetext{
1482 O.S.H.R.C. 239 (1973).

${ }^{150}$ In Fineberg Packing Co., 7 O.S.H.R.C. at 408, Commissioner Cleary also considered this issue in discussing whether section 4(b)(3) of the Act was applicable after section 4(b)(1) was rejected as a defense.

${ }_{151}$ See generally Morey, The General Duty Clause of the Occupational Safety and Health Act of 1970, 86 HARv. L. REv. 988 (1973).
} 
mission Chairman Moran has recently pointed out that some of the most frequently cited OSHA standards, such as the fire extinguisher requirements, bear little relation to occupational injury at all. ${ }^{152}$ Thus, there is the danger that OSHA preoccupation with such standards, and with achieving large numbers of inspections and citations, may detract from agency and employer efforts to prevent truly hazardous conditions. Other areas beyond the legal realm but of vital importance to the success of the statutory standards include the quality of training given workers, OSHA inspectors, and safety professionals, as well as the amount and quality of scientific research regarding hazardous conditions which may be incorporated into new statutory standards. So long as the state plan program is in effect, the quality of OSHA's supervision of the state programs is also critical.

When all is said about the many difficulties with standards, legal and otherwise, they plainly are the only viable way to proceed with the enormous task of providing occupational safety and health in the American workplace. At the same time, the proper development and enforcement of standards is an enormously complex task which will require the best talents of scientific and technical personnel, of educators and administrators, of labor and management, and also of lawyers. Without the best combination of all these diverse elements, neither fair and useful standards nor reasonable enforcement of such standards seems achievable.

${ }^{152}$ Address of Robert D. Moran, Chairman, Occupational Safety and Health Review Commission, Apr. 24, 1974. 